\title{
Syndromic Disorders Caused by Disturbed Human Imprinting
}

\author{
(1) Diana Carli, (1) Evelise Riberi, (1) Giovanni Battista Ferrero, (1) Alessandro Mussa
}

University of Torino, Department of Pediatric and Public Health Sciences, Torino, Italy

\begin{abstract}
Imprinting disorders are a group of congenital diseases caused by dysregulation of genomic imprinting, affecting prenatal and postnatal growth, neurocognitive development, metabolism and cancer predisposition. Aberrant expression of imprinted genes can be achieved through different mechanisms, classified into epigenetic - if not involving DNA sequence change - or genetic in the case of altered genomic sequence. Despite the underlying mechanism, the phenotype depends on the parental allele affected and opposite phenotypes may result depending on the involvement of the maternal or the paternal chromosome. Imprinting disorders are largely underdiagnosed because of the broad range of clinical signs, the overlap of presentation among different disorders, the presence of mild phenotypes, the mitigation of the phenotype with age and the limited availability of molecular techniques employed for diagnosis. This review briefly illustrates the currently known human imprinting disorders, highlighting endocrinological aspects of pediatric interest.
\end{abstract}

Keywords: Imprinting disorders, epimutation, genotype, phenotype

\section{Introduction}

The imprinting disorders are a group of congenital diseases caused by dysregulation of genomic imprinting that can affect fetal and postnatal growth, neurocognitive development, metabolism and cancer predisposition with relevance to pediatricians, geneticists, endocrinologists and other specialists $(1,2,3,4,5,6)$. Genomic imprinting mediates the expression of specific genes in a parent of origin specific manner. While most genes are expressed biparentally, imprinted genes are expressed only from the paternal or the maternal allele. Imprinted genes are often arranged in clusters and expressed under a coordinated epigenetic regulation $(4,7)$. Human imprinting disorders result from dysregulation of the normal expression of imprinted genes, causing altered dosage or function of such gene transcripts. This can be achieved through different mechanisms, which may involve DNA expression only (epigenetic mechanisms) or may also encompass DNA sequence (genomic mechanisms). While the former are mostly sporadic, the latter result in familial forms with a parent of origin inheritance pattern (5).

The molecular mechanisms responsible for altered imprinted gene expression (Figure 1) are classified into:
1. Uniparental disomy (UPD), which consists of the inheritance of two copies of a chromosome (or part of a chromosome) from one parent and no copy from the other parent. UPD can be heterodisomy, when both homologue chromosomes from the transmitting parent are present, or isodisomy, when two identical chromosomes from the same parental homologue are present (8).

2. Abnormal methylation (also termed epimutation) including excessive methylation (hypermethylation or gain of methylation - GoM) and reduced methylation [hypomethylation or loss of methylation (LoM)]. Abnormal methylation can be primary (i.e. in the absence of an underlying genomic cause) or secondary (i.e. due to an underlying genomic cause). While the former is sporadic, the latter is associated with a recurrence risk, in an autosomal dominant manner with parent of origin effect.

3. Chromosomal abnormalities (deletions, duplications and balanced rearrangements).

4. Intragenic variants in imprinted genes resulting in loss or gain of function.

For all these four mechanisms, the phenotype depends on the affected parental allele; in some cases, aberrations at the same locus involving either the maternal or the 
EPIGENETIC ANOMALIES

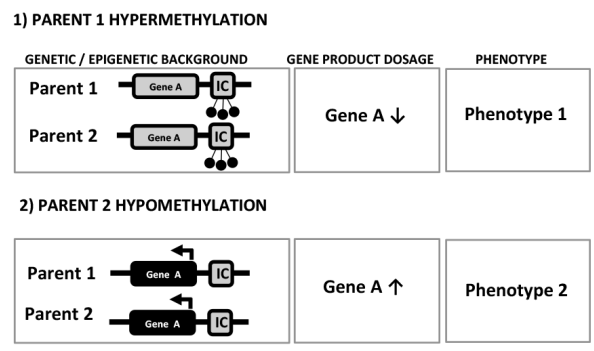

NORMAL

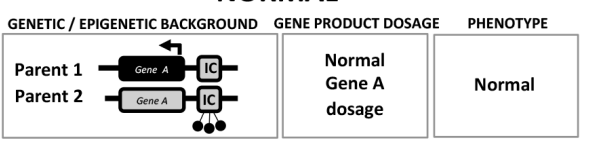

POINT MUTATIONS

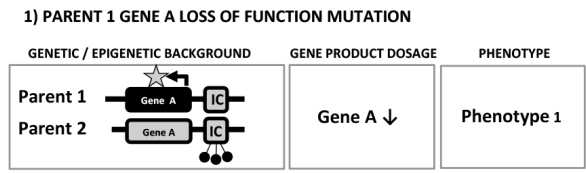

2) PARENT 2 GENE A LOSS OF FUNCTION MUTATION

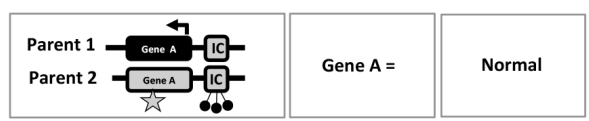

3) PARENT 1 GENE A GAIN OF FUNCTION MUTATION

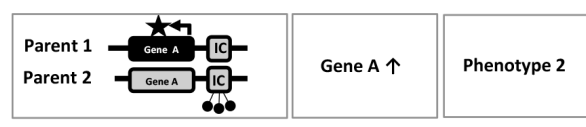

4) PARENT 2 GENE A GAIN OF FUNCTION MUTATION

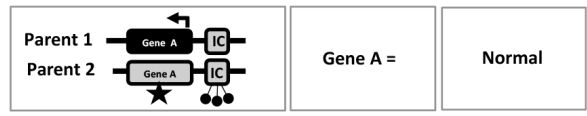

\section{CHROMOSOMAL REARRANGEMENTS}

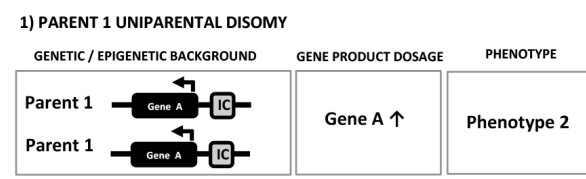

2) PARENT 2 UNIPARENTAL DISOMY

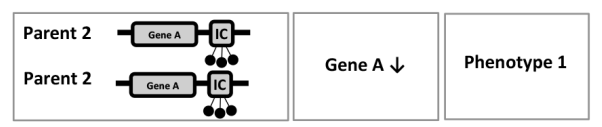

3) PARENT 1 GENE A DELETION

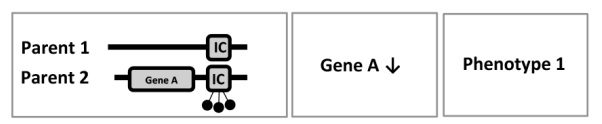

4) PARENT 2 GENE A DELETION

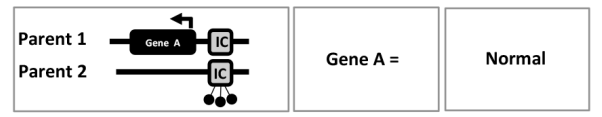

5) PARENT 1 GENE A DUPLICATION

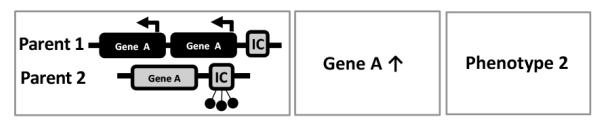

6) PARENT 2 GENE A DUPLICATION

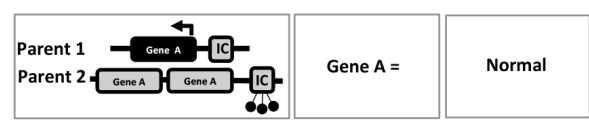

Figure 1. Schematic representation of the molecular mechanisms responsible for altered imprinted gene expression. At the top normal functioning of a paradigmatic chromosomal region subjected to imprinting is reported: on the allele inherited from parent 1, the imprinting center (IC) is unmethylated and gene A is expressed, while on the allele inherited from parent 2 , gene $\mathrm{A}$ is silenced by IC methylation. This leads to a balanced expression of gene $\mathrm{A}$, corresponding to the normal phenotype. Conversely, imbalance between the expression of the imprinted gene leads to a pathological phenotype: a deficiency of gene A leads to phenotype 1, while an excess of gene A leads to phenotype 2. Phenotype 1 and phenotype 2 may have antithetical characteristics (mirror phenotypes). In the left column, epigenetic anomalies leading to disturbed expression of imprinted genes are shown. In the middle column, point mutations and in the right column, uniparental disomy, deletion and duplication affecting the imprinted gene are reported. If the point mutation or the deletion/duplication hits the expressed gene, it will lead to a phenotype while, on the opposite, if they involve a normally silenced gene, they will not result in a phenotype: in both cases, the genetic anomaly could be transmitted to the offspring

paternal chromosome result in opposite phenotypes (Table 1). Although each imprinting disorder is characterized by specific clinical features, shared phenotypic features are common and clinical overlap occurs. Moreover, mild phenotypes, a broad clinical spectrum, mitigation of the presentation with age and limited availability of the molecular techniques employed for diagnosis probably lead to a relevant underdiagnosis $(4,5)$.
Most patients with an imprinting disorder are affected by a single disease-specific locus with a definite phenotype. However, cases with multilocus methylation imprinting disturbances (MLID) and consequent complex phenotypes are increasingly described and further complicate the clinical evaluation. Of interest, the frequency of some of the imprinting disorders is increased in the offspring of subfertile parents and likely connected with artificial reproductive techniques $(9,10)$. 
Table 1. Summary of the clinical features and the molecular mechanisms of the human imprinting disorders

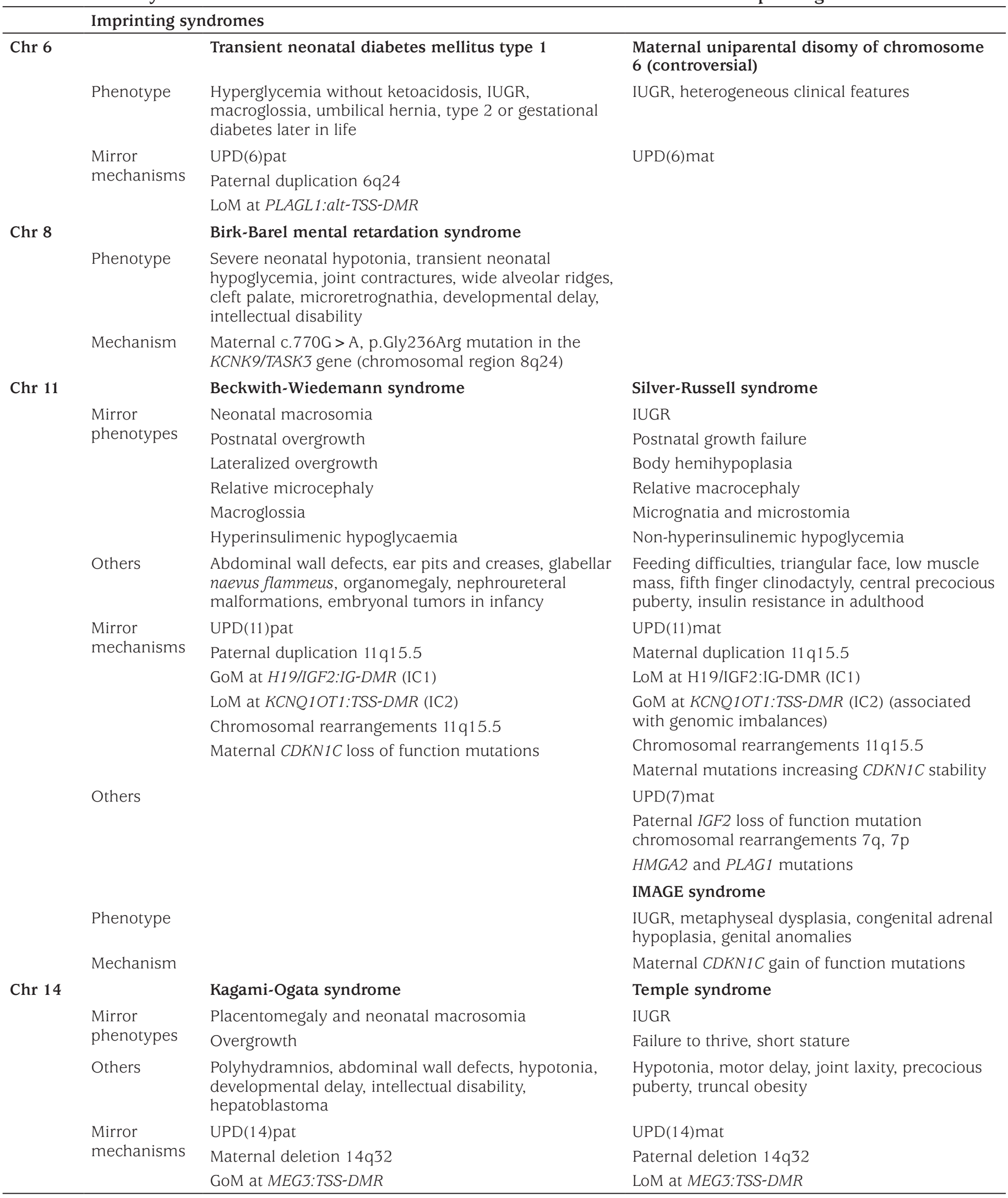




\begin{tabular}{|c|c|c|}
\hline Imprinting sy & Idromes & \\
\hline & Prader-Willi syndrome & Angelman syndrome \\
\hline & Central apnoea and hypoventilation & Seizures, sleep disruption \\
\hline & $\begin{array}{l}\text { Hypotonia, reduced spontaneous motility } \\
\text { Hypothermia and absence of fever response }\end{array}$ & $\begin{array}{l}\text { Excessive and unmotivated laugh, } \\
\text { hyperexcitability, hyperactivity and hyperreflexia, } \\
\text { happy demeanor }\end{array}$ \\
\hline & & Sensitivity to heat \\
\hline Others & $\begin{array}{l}\text { Mild to moderate intellectual disability, central obesity, } \\
\text { hypogonadotrophic hypogonadism, short stature }\end{array}$ & $\begin{array}{l}\text { Severe intellectual disability, microcephaly, } \\
\text { severe speech impairment, ataxia }\end{array}$ \\
\hline Mirror & UPD(15)mat & UPD(15)pat \\
\hline mechanisms & Paternal deletion $15 q 11$ q13 & Maternal deletion $15 q 11 q 13$ \\
\hline Phenotype & $\begin{array}{l}\text { Neonatal hypotonia, developmental delay, intellectual } \\
\text { disability, hypogonadism, autistic behavior, joints } \\
\text { contractures }\end{array}$ & \\
\hline Mechanism & Paternal MAGEL2 truncating mutations & \\
\hline & Central precocious puberty 2 & \\
\hline Phenotype & Premature activation of the reproductive axis & \\
\hline Mechanism & Paternal $M K R N 3 / Z F P 127$ loss of function mutations & \\
\hline & & $\begin{array}{l}\text { Maternal uniparental disomy of chromosome } 16 \\
\text { (controversial) }\end{array}$ \\
\hline Phenotype & & IUGR, elevated risk of malformation \\
\hline & PHP1B & Maternal uniparental disomy of chromosome 20 \\
\hline Phenotype & Isolated renal PTH resistance & $\begin{array}{l}\text { IUGR, short stature, extreme feeding difficulties, } \\
\text { failure to thrive }\end{array}$ \\
\hline $\begin{array}{l}\text { Mirror } \\
\text { mechanism }\end{array}$ & UPD(20)pat & UPD(20)mat \\
\hline $\begin{array}{l}\text { Other } \\
\text { mechanism }\end{array}$ & LoM at GNAS A/B:TSS-DMR & \\
\hline
\end{tabular}

IUGR: intrauterine growth restriction, UPD: uniparental disomy, GoM: gain of methylation, LoM: loss of methylation, PTH: parathyroid hormone, POH: progressive osseous heteroplasia, DMR: differentially methylated region

Recent advances in this field suggest that the range of imprinting disorders could be greater than those currently described. In this article we review those described hitherto, ordered by chromosome.

\section{Chromosome 6}

Transient Neonatal Diabetes Mellitus Type 1

Transient neonatal diabetes mellitus type 1 (TNDM1, OMIM \#601410) has a prevalence of approximately 1 in 500,000 births (11) and it is characterized by intra-uterine growth 
restriction (IUGR) and infantile hyperglycemia in the absence of ketoacidosis. Macroglossia and umbilical hernia are often present. TNMD1 features are evident in infants during the first weeks of life, usually presenting with dehydration, and generally disappearing by the age of 18 months. Insulin treatment is usually required. However, diabetes may relapse later in life in approximately half of the patients, showing characteristics of type 2 diabetes mellitus. Women may relapse during pregnancy presenting with gestational diabetes mellitus (12).

TNDM1 can be caused by three different molecular mechanisms (12):

1. Paternal UPD of chromosome 6 (41\%).

2. Duplication of the paternal allele at 6q24 (29\%).

3. Hypomethylation of the maternal differentially methylated region (DMR), PLAGL1: alt-TSS-DMR (30\%).

This latter mechanism can be due to either an isolated imprinting variant or as part of a generalized hypomethylation at imprinted loci (MLID), due to recessive loss of function ZFP57 mutations in almost half of the cases (13). TNDM1MLID patients may have further phenotypic manifestations, such as structural brain abnormalities, developmental delay and congenital heart disease (14).

All three molecular mechanisms accounting for TNDM1 lead to over-expression of the PLAGL1/ZAC gene which regulates apoptosis and cell cycle arrest (15). The protein encoded by the PLAGL1/ZAC gene is a zinc finger protein and regulates $P A C A P 1$ that has a key role in stimulating insulin secretion by pancreatic beta cells. Moreover, PLAGL1/ZAC1 gene overexpression may reduce the number of beta cells or impair their function, stopping cell cycling and inducing apoptosis (12).

\section{Maternal Uniparental Disomy of Chromosome 6}

Maternal UPD of chromosome 6, abbreviated to UPD(6) mat, has been hypothesized to be associated with IUGR and other heterogeneous clinical features, especially intellectual disability (16). However, homozygosity of a recessive allele and/or placental trisomy 6 mosaicism is likely to be the pathogenic mechanism in some of these patients. These data suggest that a specific imprinting disorder associated with UPD(6)mat does not exist and that the heterogeneous clinical features in UPD(6) mat patients are either caused by placental trisomy 6 , undetected trisomy 6 cell lines or by homozygosity for recessive mutations $(5,17)$. However, given the small number of patients described to date and the presence of an imprinted region on chromosome $6 \mathrm{q} 24$ further studies are required to clarify this contentious issue.

\section{Chromosome 7}

Maternal UPDs of chromosome 7 are responsible for a small subset (5-10\%) of Silver-Russell syndrome (SRS). Since the majority of SRS cases are due to chromosome 11 abnormalities, this topic is extensively described in the chromosome 11 section.

\section{Chromosome 8}

\section{Birk-Barel Syndrome}

Birk-Barel syndrome (OMIM \#612292) is characterized by severe neonatal hypotonia, transient neonatal hypoglycemia, joint contractures, wide alveolar ridges, cleft palate, microretrognathia, developmental delay and variable intellectual disability. Distinctive facial features include dolichocephaly, bitemporal narrowing, short philtrum, tented upper lip and medially flared eyebrows $(18,19)$.

This disorder is caused by a specific missense mutation (c.770G >A, p.Gly236Arg) in the maternal copy of the KCNK9/TASK3 gene, located in chromosomal region 8q24.

The $8 \mathrm{q} 24$ chromosomal region includes two imprinted genes: PEG13, expressed by the paternal allele and KCNK9, expressed by the maternal allele. The reciprocal expression of these genes is regulated by a maternal methylated region located within the PEG13 transcript, named PEG13:TSSDMR (20).

The KCNK9/TASK3 gene encodes a member of the two pore-domain potassium channel subfamily $(18,19)$. TASK3 channels are widely expressed, especially in the brain, where they play a role in the migration of cortical pyramidal neurons regulating both neuronal activity and neuronal development. Of note, nonsteroidal anti-inflammatory fenamic acid drugs, especially flufenamic acid, are able to stimulate the two pore-domain potassium channels, partially rescuing the reduced outward current through mutated KCNK9 channels, suggesting that fenamic acid compounds might be useful in treating this condition (18).

\section{Chromosome 11}

\section{Beckwith-Wiedemann Syndrome}

Beckwith-Wiedemann syndrome (BWS) (OMIM \#130650) is the most common congenital overgrowth condition (1:10,500 live births) (21) and represents the paradigm of genetic imprinting disorders and cancer predisposition 
syndromes. Clinical features include neonatal macrosomia, postnatal overgrowth, macroglossia, abdominal wall defects ranging from severe (omphalocele, gastroschisis) to moderate (umbilical hernia) and mild (diastasis recti), ear pits and creases, glabellar naevus flammeus, lateralized overgrowth (previously termed hemihyperplasia) (22), organomegaly, nephroureteral malformations (23), hyperinsulinism or transient hypoglycaemia (1), placental mesenchymal dysplasia and predisposition to the development of embryonal tumors in infancy (24). These features combine variably accounting for the different degree of severity of presentation and depicting a broad phenotypic spectrum $(25,26,27,28,29)$, including cases with isolated lateralized overgrowth (22). The diagnosis is clinical, based on criteria and a scoring system which has been recently revised (1).

BWS is caused by several epigenetic and genetic defects. In approximately $85 \%$ of patients disturbed expression of imprinted genes located into two separate domains on chromosome $11 \mathrm{p} 15.5$ is found. In this chromosomal region, two differentially methylated imprinting centers (IC) (H19/ IGF2:IG-DMR and KCNQ1OT1:TSS-DMR, commonly referred to as IC1 and IC2, respectively) control the expression of genes involved in cell cycle progression and somatic growth control. Five mechanisms leading to the disruption of the expression of such genes are currently known:

1. Approximately $50 \%$ of cases are caused by LoM at IC2 (IC2-LoM) leading to reduced expression of CDKN1C, normally expressed by the maternal chromosome only. IC2-LoM is usually a sporadic primary epigenetic defect, however rare familial cases carrying genetic mutations causing secondary hypomethylation have been described (30). An increasingly growing fraction of patients with IC2-LoM also display methylation abnormalities at other imprinted loci leading to additional phenotypes (MLID) $(31,32)$. Disruption of trans-acting mechanisms regulating the normal imprinting at the 11 p15.5 ICs as well as other differentially methylated regions can be responsible for such cases; rare inheritable mutations in the NLRP family genes have been described $(33,34,35)$. NLRP proteins are members of the NLR family of proteins and are important components of inflammasomes with a major role in innate immunity (36). Interestingly, a subset of $N L R P$ genes is expressed in oocytes and early embryos (37). Females with mutations in NLRP2 and NLRP7 gave birth to few or no liveborn children (38). Germline mutations in NLRP2 are responsible for a familial form of BWS caused by a trans-acting mechanism, consistent with the hypothesis that NLRP2 has a role in establishing or maintaining genomic imprinting in humans (33).
NLRP5 mutations have also been reported in five mothers of offspring with MLID, linking this gene with a maternal effect on reproductive fitness, epigenetic and developmental reprogramming of zygotes and reproductive outcomes $(32,39)$.

2. Mosaic segmental paternal UPD of chromosome 11, accounting for $20 \%$ of the cases, leads to altered expression at both gene clusters (1) with IC2-LoM and IC1-GoM. Genome-wide UPD of chromosome 11 is found in a subset of cases and associated with higher cancer risk (40).

3. IC1-GoM results in biallelic expression of the IGF2 gene which is normally expressed by the paternal allele only and reduced expression of the $H 19$ gene, an oncosuppressor gene normally expressed by the maternal allele. IC1-GoM is found in $5-10 \%$ of cases and in a subset of patients is caused by microdeletions encompassing the OCT4/SOX2 binding site localized inside $\mathrm{IC} 1$, leading to a maternally transmitted BWS phenotype $(41,42)$.

4. Maternal CDKN1C loss-of-function mutations are responsible for maternally inheritable BWS and account for 5-10\% of cases.

5. Finally, approximately $1 \%$ of BWS cases are caused by chromosomal rearrangements (duplications, translocations, inversions, deletions) involving the 11 p15.5 chromosomal region and causing secondary IC1-GoM or IC2-LoM (24).

About $15 \%$ of clinically diagnosed BWS cases have no detectable molecular defect when investigated using commonly employed diagnostic molecular techniques. However, low somatic mosaicism of the above mentioned defects is increasingly found by using novel molecular techniques (43) and analysing tissues other than blood (e.g. buccal smear) (44). It cannot be excluded that in a fraction of patients the molecular defect has not yet been discovered.

Besides providing diagnostic confirmation and the possibility of genetic counselling, molecular anomalies detected in BWS have implications for the clinical management of patients and prognostic value. Indeed, specific correlation between epigenotype and phenotypic features are present, especially concerning cancer risk $(26,27,28,45)$. BWS molecular subtypes are characterized by a gradient in cancer development probability and display different histotypes allowing differentiation of tumor surveillance protocols according to the epigenotype. This facilitates the early detection of relevant associated tumors, with special reference to Wilms' tumor and hepatoblastoma $(26,45,46,47,48,49,50,51,52)$. 


\section{Silver-Russel Syndrome}

SRS (OMIM \#180860) is the phenotypic and genetic opposite disorder of BWS, has an estimate incidence of $1: 30,000$ to $1: 100,000$ (2) and represents the paradigm of genetic restricted growth imprinting disorders and poor feeding predisposition.

The phenotypic clinical spectrum of SRS includes severe IUGR, postnatal growth failure with no catch-up, body hemihypoplasia with body asymmetry, relative macrocephaly with triangular face, typical facial appearance (prominent forehead, narrow chin, small jaw and downturned corners of the mouth), low muscle mass, fifth finger clinodactyly, feeding difficulties, recurrent hypoglycemia, premature adrenarche, rapidly progressing and/or central precocious puberty (CPP) and insulin resistance in adulthood $(2,53)$.

The diagnosis of SRS is clinical and molecular testing is used for confirmation and phenotype stratification. Given the broad spectrum of presentation, the diagnosis is based on the Netchine-Harbison scoring system (54), having high sensitivity and predictive value. A molecular cause can be identified in approximately $60 \%$ of patients with a clinical diagnosis (2), while the molecular aetiology remains unknown in a substantial proportion of patients:

1. The most common mechanisms is LoM at IC1 on the paternal chromosome $11 \mathrm{p} 15$ (IC1-LoM), which is detected in $40-60 \%$ of patients. IC1-LoM results in reduced IGF2 expression and increased H19 expression $(2,55)$.

2. Besides IC1-LoM, a variety of rearrangements involving the 11 p15.5 region resulting in a SRS phenotype have been described $(56,57)$.

3. From 5 to $10 \%$ of cases are caused by maternal UPD of chromosome 7 (2).

4. Mirroring BWS molecular alterations in chromosomal region $11 \mathrm{p} 15.5$, the SRS phenotype also results from alterations at the centromeric IC2 of 11 p15.5. Genomic imbalances involving IC2 resulting in gain of methylation at this center have been rarely described (58).

5. Rare monogenic causes have been described including a mutation increasing CDKN1C stability in a family with maternally transmitted SRS (59), IGF2 loss-of-function mutation in a family with paternally transmitted SRS (60) and HMGA2 and PLAG1 mutations with dominant transmission regardless of maternal or paternal transmission $(61,62,63)$. Coding variants in these genes are overall very rare (2).

Differential diagnosis of SRS includes other genetic syndromes characterized by growth restriction, including single gene disorders such as IMAGE syndrome (discussed immediately below) and Temple syndrome (discussed in the chromosome 14 section) and chromosomal anomalies and copy number variants (2). The differential diagnosis can have extremely important implications for management since SRS treatment may include growth hormone (GH) therapy (53) and response to treatment. For instance, GH treatment is contraindicated in patients with chromosome breakage disorders due to the associated risk of malignancy (2).

\section{IMAGE Syndrome}

IMAGE syndrome (OMIM \#614732) results from a gainof-function mutation in the CDKN1C gene, negatively regulating cellular proliferation. Since CDKN1C is expressed only from the maternal allele, IMAGE syndrome occurs only when the CDKN1C gain-of-function mutation is inherited from the mother (64). This syndrome is characterized by SRS phenotype associated with metaphyseal dysplasia, congenital adrenal hypoplasia with adrenal insufficiency, and almost always includes genital anomalies (65).

\section{Chromosome 14}

\section{Temple Syndrome}

Temple syndrome (OMIM \#616222) is characterized by prenatal and postnatal growth failure and early onset of puberty with final short stature, hypotonia, feeding difficulties in early childhood, motor delay, joint laxity, truncal obesity and minor dysmorphic features such as broad forehead and short nose with wide nasal tip and small hands and feet (66). Due to relatively mild and age-dependent characteristics, the prevalence of Temple syndrome in the general population is unknown and the disorder is likely underdiagnosed in clinical practice (66).

Temple syndrome shows several nonspecific clinical features overlapping with Prader-Willi syndrome (PWS) and SRS $(67,68,69)$. The treatment may include GH therapy (70).

The syndrome is caused by alteration of imprinted gene expression at chromosome $14 q 32.2$. This region contains a cluster of imprinted genes including three paternally expressed genes (DLK1, DIO3 and RTL1) and multiple maternally expressed non-coding RNAs (MEG3, RTL1as, MEG8, snoRNAs, and microRNAs) (71). The parental origindependent expression patterns are regulated by a germlinederived primary intergenic DMR (MEG3/DLK1:IG-DMR) and a postfertilization-derived secondary DMR (MEG3:TSS$D M R$ ), both normally methylated only on the paternal allele (72). Mechanisms that result in functional hemizygosity of 
$14 q 32$ imprinted genes can cause the clinical phenotypes (4), including:

1. Chromosome 14 maternal UPD (78\%) (73).

2. Isolated methylation deficiency at MEG3:TSS-DMR in the $14 q 32.2$ imprinted region (12\%) (74).

3. $14 q 32$ deletions of paternal origin (10\%) (71).

Maternal UPD of chromosome 14 represents the major molecular cause of Temple syndrome. However, some evidence indicate that UPD over-representation among the molecular causes of Temple's syndrome could be due to an ascertainment bias and it is possible that frequencies of the molecular findings in Temple syndrome will be updated in the coming years (75).

\section{Kagami-Ogata Syndrome}

Kagami-Ogata syndrome (OMIM \#608149) includes overgrowth (typically with birth weight disproportionately greater than length), polyhydramnios, placentomegaly, poor sucking and hypoventilation in the neonatal period, abdominal wall defects ranging from omphalocele to diastasis recti, a distinctive facial appearance (full cheeks, depressed nasal bridge, micrognathia, short webbed neck and protruding philtrum), small bell-shaped thorax with coat-hanger ribs, and variable developmental delay and/or intellectual disability. Some features are rather nonspecific and can be also observed in BWS. Kagami-Ogata syndrome is associated with increased risk of developing hepatoblastoma (9\%) and a neonatal mortality rate as high as $20-25 \%$ (76).

Kagami-Ogata syndrome can be caused by three different molecular mechanisms (4):

1. Paternal UPD of chromosome 14 (65\%).

2. Microdeletion affecting the maternal $14 q 32.2$ imprinted region $(20 \%)$.

3. Hypermethylation (15\%) affecting the MEG3:TSS-DMR in the maternal 14q32.2 imprinted region (77).

While UPD(14)pat and hypermethylation are sporadic, microdeletions can lead to a maternally transmitted KagamiOgata syndrome. Recently it has been shown that causal deletions do not necessarily include the DMRs; therefore, a normal methylation pattern does not exclude the syndrome (78).

As discussed for Temple's syndrome, it has been proposed that over-representation of UPD(14)pat among the molecular causes of the Kagami-Ogata syndrome could be secondary to an ascertainment bias and the frequencies of the molecular causes could change as availability of specific molecular tests increases (75).

\section{Chromosome 15}

\section{Angelman Syndrome}

Angelman syndrome (AS) (OMIM \# 105830) is characterized by developmental delay, intellectual disability with severe speech impairment, microcephaly and seizures. The symptoms usually appear in the first year of life (79). Seizures typically occur between one and three years of age and can be associated with generalized, specific electroencephalographic changes (80). Patients also present with sleep disruption, excessive laughter, happy demeanor, gait ataxia, tremulousness of the limbs and protruding tongue. AS prevalence is approximately one in 12,00024,000 live births (80).

AS can be caused by four different mechanisms:

1. Maternally derived de novo deletion of 15q11-q13 (70$75 \%)$.

2. Paternal UPD of chromosome 15 (3-7\%).

3. Imprinting defect at MKRN3:TSS-DMR in the maternal chromosome 15q11.2-q13 locus (2-3\%).

4. Maternally inherited mutations in UBE3A gene (10-15\%) (5).

The phenotype is usually more severe in patients with large deletions. All genetic mechanisms result in lack of expression of the maternally expressed 15q11-q13 UBE3A gene. UBE3A is normally expressed exclusively from the maternal allele in human fetal brain and in adult frontal cortex. Duplications of this gene have been linked to autism spectrum disorder, developmental delay and neuropsychiatric phenotypes (81), further supporting the hypothesis that UBE3A plays a pivotal role in neurodevelopment. AS patients have a paternal copy of $U B E 3 A$, but it is silenced by a nuclear localized long noncoding RNA, known as UBE3A antisense transcript (UBE3AATS) (82). Antisense oligonucleotides treatment aimed at reducing the UBE3A-ATS in order to unsilence the paternal UBE3A gene is under study (82).

\section{Prader-Willi Syndrome}

PWS (OMIM \#176270) includes variable characteristics according to the age of the patient. Decreased fetal movement, abnormal fetal position at delivery, and increased incidence of assisted delivery or cesarean section are common. Hypotonia of central origin with poor sucking and feeding difficulties resulting in failure to thrive are prevalent in the neonatal period and in the first year of life. 
Subsequently, progressive hyperphagia with central obesity occurs. Hyperphagia is linked to a hypothalamic dysfunction resulting in lack of satiety and food-seeking behavior with central obesity being the result of both hyperphagia and a reduced total energy expenditure connected with decreased physical activity and decreased lean body mass. Extreme obesity and related complications represent the major causes of morbidity and mortality in PWS (83). Hypothalamic hypogonadism with cryptorchidism, incomplete genital development, delayed and incomplete puberty and infertility are typical (84). Short stature is very common and is usually treated with GH replacement therapy, with the additional benefit of acquisition of lean mass. Abnormalities of GH function in PWS have been reported and other hypothalamic hormones can also be deficient causing tertiary hypothyroidism, and central adrenal insufficiency (85). PWS patients may exhibit developmental delay of variable severity. Behavior problems are common and manifest with a typical pattern including temper tantrums, controlling and manipulative behavior and compulsivity. Current trials are underway to evaluate oxytocin as a potential therapeutic agent for controlling behavior issues in PWS patients $(86,87)$.

Characteristic facial features may develop over time and include narrow bifrontal diameter and nasal bridge, almondshaped palpebral fissures, thin vermilion of the upper lip with down-turned corners of the mouth.

Diagnosis and molecular testing is based on clinical criteria (88).

PWS is caused by lack of expression of imprinted genes on chromosome 15q11.2-q13 gene cluster, defined as the "PWS critical region". Alterations not involving this critical region are not associated with PWS. The PWS critical region encompasses imprinted genes normally expressed only on the paternal allele: MKRN3, MAGEL2, NDN, PWRN1, C15orf2, SNURF-SNRPN and several snoRNA genes. The deficiency of one of these snoRNA (SNORD116) is believed to elicit the key features of PWS phenotype $(89,90)$.

Altered expression can be caused by four mechanisms:

1. Deletion of the 15q11-q13 imprinted loci on the paternal allele (up to $70-75 \%$ of cases).

2. Maternal UPD of chromosome 15 (up to 20-25\%).

3. Imprinting defects due to primary epimutations at MKRN3:TSS-DMR (2\%) $(84,91)$.

4. Small deletions within the IC critical region which may or may not lead to an imprinting deficiency detectable by methylation analysis $(<0.5 \%)(84,91,92)$.
Most PWS cases are sporadic. Inheritable PWS is rare and can be due to deletions caused by unbalanced chromosome rearrangement or paternally inherited IC deletion. The diagnosis is confirmed through DNA methylation analysis, with subsequent cytogenetic testing, fluorescence in situ hybridization and microsatellite marker analysis, which define the genotype classifications (93).

\section{Schaaf-Yang Syndrome}

Schaaf-Yang syndrome (OMIM \#615547) is a PWS-like disease, due to truncating mutations in the MAGEL2 gene, which is located in the PWS critical region (chromosome 15q11-q13) and is normally maternally imprinted and paternally expressed. Schaaf-Yang syndrome is characterized by neonatal hypotonia, developmental delay and intellectual disability, hypogonadism, autistic behavior and joints contractures. The typical PWS features of hyperphagia and obesity are usually absent. Consequently, the phenotypic overlap with PWS is preeminent in the neonatal period. The phenotypic spectrum ranges from severe fetal akinesia to mild expression including intellectual disability and finger contractures (94).

Paradoxically, while truncating mutations in the MAGEL2 gene cause Schaaf-Yang syndrome, MAGEL2 whole gene deletions cause on slight or even absent expression of the clinical phenotype (94). It is likely, as MAGEL2 is a one-exon gene, that truncating mutations may result in a shortened protein with a dominant-negative effect. As an alternative explanation to this phenomenon, the deletion of the entire paternal copy of the gene, including its promoter, could lead to leaky expression of the maternal copy of the gene (94).

\section{Central Precocious Puberty 2}

CPP (OMIM \#176400) also known as gonadotropin dependent precocious puberty, is characterized by a premature activation of the reproductive axis, before the age of eight years in girls and nine years in boys (95). Prevalence of CPP has been estimated at approximately 1.1:100,000 with an overall male to female ratio of at least 1:10 (96). Subjects affected by CPP present with pubertal signs such as breast development or testicular enlargement and acceleration of growth and bone age, consistent with elevated basal and GnRH-stimulated LH levels (97).

CPP 2 (CPPB2, OMIM \#615346) is caused by heterozygous loss of function mutations in the MKRN3/ZFP127 gene, located in the PWS critical region (chromosome 15q11-q13). An antisense RNA of unknown function overlaps this gene, probably regulating MKRN3/ZFP127 expression. MKRN3/ 
ZFP127 is maternally imprinted and paternally expressed. Therefore only mutations inherited from fathers are disease-causing (97). It is noteworthy that a high frequency of MKRN3/ZFP127 mutations was reported in a cohort of CCP males with anticipated puberty (98).

Puberty in humans normally starts when pulsatile GnRH is released from hypothalamic neurons. Indeed, the onset of puberty requires both a decrease in factors that inhibit the release of GnRH and an increase in stimulatory factors. MKRN3/ZFP127 protein levels declined prior to clinical onset of puberty and thereafter through puberty, which correlated negatively with gonadotropin concentrations in prepubertal girls (99) and its circulating levels declined during puberty in healthy boys (100). The expression pattern of MKRN3/ ZFP127 suggests the hypothesis of an inhibitory effect on GnRH secretion (101) but the precise mechanism by which its deficiency leads to an early reactivation of pulsatile GnRH secretion remains to be elucidated (95).

GnRH agonists have been the standard of care for the management of CPP in order to decrease bone maturation, growth velocity and progression of clinical signs of puberty (102).

\section{Chromosome 16}

\section{Maternal Uniparental Disomy of Chromosome 16}

UPD(16)mat has a high frequency since it is caused by trisomy 16 rescue (103). UPD(16)mat is associated with IUGR with an elevated risk of malformation but without a unique and specific phenotype. The heterogeneity of the phenotype suggests that placental insufficiency or mosaicism for trisomy 16 may be responsible for symptoms in such patients $(36,104,105)$. Taken together, these data seem to indicate, as for UPD(6)mat, that a specific chromosome 16 associated imprinting disorder does not exist (105). On the other hand, some imprinted genes with unknown function have been identified on chromosome 16 and further studies are required to clarify the issue (106).

\section{Chromosome 20}

\section{Pseudohypoparathyroidism}

Pseudohypoparathyroidism (PHP) is a heterogeneous group of endocrine disorders characterized by renal resistance to parathyroid hormone (PTH), causing hypocalcaemia, hyperphosphatemia and elevated circulating PTH levels $(3,107)$. Depending on the molecular defect, PHP includes other endocrine deficiencies related to hormone action resistance and other non-endocrine features. Overall, prevalence of PHP has been estimated to be 1.1 in $100,000(108,109,110)$.
GNAS is a complex imprinting locus resulting in maternally, paternally, or biallelically expressed transcripts in differentially imprinted tissues: Gs $\alpha$, the alpha-stimulatory subunit of the G protein; XL $\alpha S ; A / B$; NESP; and the antisense transcript GNAS-AS1. The antisense transcript GNAS-AS1, $A / B$ and $X L \alpha S$ are transcribed from the paternal allele only; NESP is transcribed from the maternal allele only, and Gs $\alpha$ has a biallelical expression in most tissues, while its expression is restricted to the maternal allele in some others, including renal proximal tubule, thyroid, pituitary gland and gonads (111), even if the promoter of Gs $\alpha$ is not differentially methylated. The GNAS locus has two different IC regions (112); the first one is located within the STX16 gene and controls the establishment of imprinting at the GNAS $A / B$ :TSS-DMR only, while the second one, encompassing the antisense transcript GNAS-AS1 on exons 3-4, controls the establishment of imprinting over the entire GNAS locus (111). Isolated imprinting defects at GNAS A/B:TSS-DMR are associated with deletions in the maternal allele affecting STX16 and/or NESP, while overall imprinting alteration at the four DMRs of the GNAS locus is caused by maternal deletions at exons 3 and 4 , or 40 and 33bp microdeletions at introns 4 and 3 of $\operatorname{GNAS-AS1}(3,111)$.

PHP type 1a (PHP1A, OMIM \#103580) is caused by loss of function mutations in the maternal allele of GNAS gene. PHP1A patients present with generalized hormone resistance of variable degree, intellectual disability, obesity connected with decreased resting energy expenditure (113), and Albright hereditary osteodystrophy (AHO). AHO includes short stature, round facies, subcutaneous ossifications, brachydactyly and other skeletal anomalies (107).

Loss of function of Gs $\alpha$ on the paternal allele can cause pseudopseudohypoparathyroidism (PPHP) (OMIM \#612463). Since renal tubular cells predominantly express the maternal allele of GNAS, a paternally inherited mutation results in a normal renal response to PTH, causing AHO without concurrent endocrine abnormalities (114). Paternal loss of function mutations can also cause progressive osseous heteroplasia (OMIM\# 166350), a condition characterized by subcutaneous ossifications presenting during childhood and progressing to involve subcutaneous and deep connective tissues, in the absence of AHO or hormone resistance (115).

Both PHP1A and PPHP individuals have halved Gsa expression in erythrocytes, which normally have a biallelic expression of GNAS. AHO may be caused by Gs $\alpha$ haploinsufficiency in tissues with GNAS biallelic expression (116).

In contrast, PHP type 1b (PHP1B, OMIM \#603233) is clinically characterized by isolated renal PTH resistance and 
in some cases by thyroid stimulating hormone resistance. Rarely, these patients show an AHO phenotype (117). Interestingly, Gs $\alpha$ expression in erythrocytes is mildly reduced in patients with AHO (116). All patients with PHP1B have, at least, LoM at GNAS A/B:TSS-DMR, likely leading to the downregulated expression of the GNAS-Gsa transcript in imprinted tissues (111). Hormonal resistance is caused by LoM on the maternally inherited allele (118). Overall, $20 \%$ of PHP1B cases are inherited and caused by the previously mentioned deletions at the ICs, while the remaining $80 \%$ are sporadic and associated with methylation defects encompassing the whole GNAS locus. A small subset of the sporadic PHP1B cases is due to paternal UPD of chromosome 20q (6). Duplications and deletions in the GNAS locus have been identified in a few patients (119) but the majority of cases are still of unknown aetiology.

PHP patients should be screened for GH deficiency with the aim of eventually starting $\mathrm{GH}$ replacement therapy. Hypocalcaemia should be treated with an active form of vitamin D and calcium supplementation. Associated endocrinopathies, such as hypothyroidism and hypogonadism, should be treated. Surgical excision of AHO subcutaneous ossifications should only be considered in the presence of delimited, superficial lesions associated with pain and/or movement impairment (3).

\section{Maternal Uniparental Disomy of Chromosome 20}

UPD(20)mat, generally caused by trisomy rescue after meiosis 2 nondisjunction, is characterized by IUGR, short stature and extreme feeding difficulties with failure to thrive from birth, often requiring gastric tube feeding in the first years of life. GH supplementation has been suggested as probably safe and effective for this condition (120). UPD(20) mat presents with phenotypic overlap with SRS, and must be considered in the SRS differential diagnosis (2).

\section{Conclusion}

The imprinting disorders represent a rapidly evolving field in medicine and genetics. Their paradigm challenges traditional molecular diagnostic techniques and genetic counselling. A precise molecular diagnosis is essential and further clinical phenotyping is needed to provide the appropriate means for accurate management of these disorders.

Besides those described, it is likely that more imprinting disorders remain to be identified. This review briefly illustrated the rapidly evolving advances in the understanding of human genomic imprinting and related disorders. Novel discoveries in this field will likely occur in the next decade and will offer the potential for more precise molecular diagnosis and clinical definition, as well as the model for novel diagnostic and therapeutic techniques directed towards personalized medicine in the fields of growth, metabolism and cancer.

\section{Ethics}

Peer-review: Externally and internally peer-reviewed.

\section{Authorship Contributions}

Concept: Alessandro Mussa, Design: Giovanni Battista Ferrero, Alessandro Mussa, Data Collection or Processing: Diana Carli, Evelise Riberi, Analysis or Interpretation: Giovanni Battista Ferrero, Alessandro Mussa, Literature Search: Diana Carli, Evelise Riberi, Writing: Diana Carli, Evelise Riberi.

Financial Disclosure: The authors declared that this study received no financial support.

\section{References}

1. Brioude F, Kalish JM, Mussa A, Foster AC, Bliek J, Ferrero GB, Boonen SE, Cole T, Baker R, Bertoletti M, Cocchi G, Coze C, De Pellegrin M, Hussain K, Ibrahim A, Kilby MD, Krajewska-Walasek M, Kratz CP, Ladusans EJ, Lapunzina P, Le Bouc Y, Maas SM, Macdonald F, Õunap K, Peruzzi L, Rossignol S, Russo S, Shipster C, Skórka A, TattonBrown K, Tenorio J, Tortora C, Grønskov K, Netchine I, Hennekam RC, Prawitt D, Tümer Z, Eggermann T, Mackay DJG, Riccio A, Maher ER. Expert consensus document: Clinical and molecular diagnosis, screening and management of Beckwith-Wiedemann syndrome: an international consensus statement. Nat Rev Endocrinol 2018;14:229249. Epub 2018 Jan 29

2. Wakeling EL, Brioude F, Lokulo-Sodipe O, O’Connell SM, Salem J, Bliek J, Canton AP, Chrzanowska KH, Davies JH, Dias RP, Dubern B, Elbracht M, Giabicani E, Grimberg A, Grønskov K, HokkenKoelega AC, Jorge AA, Kagami M, Linglart A, Maghnie M, Mohnike K, Monk D, Moore GE, Murray PG, Ogata T, Petit IO, Russo S, Said E, Toumba M, Tümer Z, Binder G, Eggermann T, Harbison MD, Temple IK, Mackay DJ, Netchine I. Diagnosis and management of SilverRussell syndrome: first international consensus statement. Nat Rev Endocrinol 2016;13:105-124. Epub 2016 Sep 2

3. Mantovani G, Bastepe M, Monk D, de Sanctis L, Thiele S, Usardi A, Ahmed SF, Bufo R, Choplin T, De Filippo G, Devernois G, Eggermann T, Elli FM, Freson K, García Ramirez A, Germain-Lee EL, Groussin L, Hamdy N, Hanna $\mathrm{P}$, Hiort $\mathrm{O}$, Jüppner $\mathrm{H}$, Kamenický $\mathrm{P}$, Knight $\mathrm{N}$, Kottler ML, Le Norcy E, Lecumberri B, Levine MA, Mäkitie O, Martin R, Martos-Moreno GÁ, Minagawa M, Murray P, Pereda A, Pignolo R, Rejnmark L, Rodado R, Rothenbuhler A, Saraff V, Shoemaker AH, Shore EM, Silve C, Turan S, Woods P, Zillikens MC, Perez de Nanclares G, Linglart A. Diagnosis and management of pseudohypoparathyroidism and related disorders: first international Consensus Statement. Nat Rev Endocrinol 2018;14:476-500.

4. Soellner L, Begemann M, Mackay DJ, Grønskov K, Tümer Z, Maher ER, Temple IK, Monk D, Riccio A, Linglart A, Netchine I, Eggermann T. Recent Advances in Imprinting Disorders. Clin Genet 2017;91:3-13. Epub 2016 Aug 4

5. Eggermann T, Perez de Nanclares G, Maher ER, Temple IK, Tümer Z, Monk D, Mackay DJ, Grønskov K, Riccio A, Linglart A, Netchine 
I. Imprinting disorders: a group of congenital disorders with overlapping patterns of molecular changes affecting imprinted loci. Clin Epigenetics 2015;7:123.

6. Eggermann T, Netchine I, Temple IK, Tümer Z, Monk D, Mackay D, Grønskov K, Riccio A, Linglart A, Maher ER. Congenital imprinting disorders: EUCID.net - a network to decipher their aetiology and to improve the diagnostic and clinical care. Clin Epigenetics 2015;7:23.

7. Hanna CW, Kelsey G. The specification of imprints in mammals. Heredity (Edinb) 2014;113:176-183. Epub 2014 Jun 18

8. Robinson WP. Mechanisms leading to uniparental disomy and their clinical consequences. Bioessays 2000;22:452-459.

9. Eroglu A, Layman LC. Role of ART in imprinting disorders. Semin Reprod Med 2012;30:92-104. Epub 2012 Apr 27

10. Mussa A, Molinatto C, Cerrato F, Palumbo O, Carella M, Baldassarre G, Carli D, Peris C, Riccio A, Ferrero GB. Assisted reproductive techniques and risk of Beckwith-Wiedemann syndrome. Pediatrics 2017;20164311. Epub 2017 Jun 20

11. Temple IK, Shield JP. 6q24 transient neonatal diabetes. Rev Endocr Metab Disord 2010;11:199-204.

12. Temple IK, Mackay DJ. Diabetes Mellitus, 6q24-Related Transient Neonatal. In: Adam MP, Ardinger HH, Pagon RA, Wallace SE, Bean LJ, Stephens K (eds). GeneReviews ${ }^{\circledR}$ [Internet]. Seattle (WA): University of Washington, Seattle; 1993 [cited 2019 Jan 16]. Available from: http://www.ncbi.nlm.nih.gov/books/NBK1534/

13. Mackay DJ, Callaway JL, Marks SM, White HE, Acerini CL, Boonen SE, Dayanikli P, Firth HV, Goodship JA, Haemers AP, Hahnemann JM, Kordonouri O, Masoud AF, Oestergaard E, Storr J, Ellard S, Hattersley AT, Robinson DO, Temple IK. Hypomethylation of multiple imprinted loci in individuals with transient neonatal diabetes is associated with mutations in ZFP57. Nat Genet 2008;40:949-951. Epub 2008 Jul 11

14. Boonen SE, Pörksen S, Mackay DJ, Oestergaard E, Olsen B, BrondumNielsen K, Temple IK, Hahnemann JM. Clinical characterisation of the multiple maternal hypomethylation syndrome in siblings. Eur J Hum Genet 2008;16:453-461. Epub 2008 Jan 16

15. Docherty LE, Poole RL, Mattocks CJ, Lehmann A, Temple IK, Mackay DJ. Further refinement of the critical minimal genetic region for the imprinting disorder 6q24 transient neonatal diabetes. Diabetologia 2010;53:2347-2351. Epub 2010 Jul 30

16. Poke G, Doody M, Prado J, Gattas M. Segmental Maternal UPD6 with Prenatal Growth Restriction. Mol Syndromol 2013;3:270-273. Epub 2012 Nov 20

17. Eggermann T, Oehl-Jaschkowitz B, Dicks S, Thomas W, Kanber D, Albrecht B, Begemann M, Kurth I, Beygo J, Buiting K. The maternal uniparental disomy of chromosome 6 (upd(6)mat) "phenotype": result of placental trisomy 6 mosaicism? Mol Genet Genomic Med 2017;5:668-677. Epub 2017 Sep 22

18. Graham JM Jr, Zadeh N, Kelley M, Tan ES, Liew W, Tan V, Deardorff MA, Wilson GN, Sagi-Dain L, Shalev SA. KCNK9 imprinting syndromefurther delineation of a possible treatable disorder. Am J Med Genet A 2016;170:2632-2637. Epub 2016 May 6.

19. Barel O, Shalev SA, Ofir R, Cohen A, Zlotogora J, Shorer Z, Mazor G, Finer G, Khateeb S, Zilberberg N, Birk OS. Maternally Inherited Birk Barel Mental Retardation Dysmorphism Syndrome Caused by a Mutation in the Genomically Imprinted Potassium Channel KCNK9. Am J Hum Genet 2008;83:193-199.

20. Court F, Camprubi C, Garcia CV, Guillaumet-Adkins A, Sparago A, Seruggia D, Sandoval J, Esteller M, Martin-Trujillo A, Riccio A, Montoliu L, Monk D. The PEG13-DMR and brain-specific enhancers dictate imprinted expression within the $8 \mathrm{q} 24$ intellectual disability risk locus. Epigenetics Chromatin 2014;7:5.
21. Mussa A, Russo S, De Crescenzo A, Chiesa N, Molinatto C, Selicorni A, Richiardi L, Larizza L, Silengo MC, Riccio A, Ferrero GB. Prevalence of beckwith-wiedemann syndrome in North West of Italy. Am J Med Genet A 2013;161:2481-2486. Epub 2013 Aug 5

22. Kalish JM, Biesecker LG, Brioude F, Deardorff MA, Di Cesare-Merlone A, Druley T, Ferrero GB, Lapunzina P, Larizza L, Maas S, Macchiaiolo M, Maher ER, Maitz S, Martinez-Agosto JA, Mussa A, Robinson P, Russo S, Selicorni A, Hennekam RC. Nomenclature and definition in asymmetric regional body overgrowth. Am J Med Genet A 2017; 173:1735-1738. Epub 2017 May 5

23. Mussa A, Peruzzi L, Chiesa N, De Crescenzo A, Russo S, Melis D, Tarani L, Baldassarre G, Larizza L, Riccio A, Silengo M, Ferrero GB. Nephrological findings and genotype-phenotype correlation in Beckwith-Wiedemann syndrome. Pediatr Nephrol 2012;27:397-406. Epub 2011 Oct 21

24. Shuman C, Beckwith JB, Weksberg R. Beckwith-Wiedemann Syndrome. In: Adam MP, Ardinger HH, Pagon RA, Wallace SE, Bean LJ, Stephens K (eds). GeneReviews ${ }^{\circledR}$ [Internet]. Seattle (WA): University of Washington, Seattle; 1993 [cited 2019 Jan 16]. Available from: http://www.ncbi.nlm.nih.gov/books/NBK1394/

25. Mussa A, Russo S, De Crescenzo A, Freschi A, Calzari L, Maitz S, Macchiaiolo M, Molinatto C, Baldassarre G, Mariani M, Tarani L, Bedeschi MF, Milani D, Melis D, Bartuli A, Cubellis MV, Selicorni A, Cirillo Silengo M, Larizza L, Riccio A, Ferrero GB. (Epi) genotypephenotype correlations in Beckwith-Wiedemann syndrome. Eur J Hum Genet 2016;24:183-190. Epub 2015 Apr 22

26. Brioude F, Lacoste A, Netchine I, Vazquez MP, Auber F, Audry G, Gauthier-Villars M, Brugieres L, Gicquel C, Le Bouc Y, Rossignol S. Beckwith-Wiedemann syndrome: growth pattern and tumor risk according to molecular mechanism, and guidelines for tumor surveillance. Horm Res Paediatr 2013;80:457-465. Epub 2013 Dec 4

27. Mussa A, Russo S, Larizza L, Riccio A, Ferrero GB. (Epi)genotypephenotype correlations in Beckwith-Wiedemann syndrome: a paradigm for genomic medicine. Clin Genet 2016;89:403-415.

28. Ibrahim A, Kirby G, Hardy C, Dias RP, Tee L, Lim D, Berg J, MacDonald F, Nightingale P, Maher ER. Methylation analysis and diagnostics of Beckwith-Wiedemann syndrome in 1,000 subjects. Clin Epigenetics 2014;6:11.

29. Mussa A, Russo S, de Crescenzo A, Freschi A, Calzari L, Maitz S, Macchiaiolo M, Molinatto C, Baldassarre G, Mariani M, Tarani L, Bedeschi MF, Milani D, Melis D, Bartuli A, Cubellis MV, Selicorni A, Silengo MC, Larizza L, Riccio A, Ferrero GB. Fetal growth patterns in Beckwith-Wiedemann syndrome. Clin Genet 2016;90:21-27. Epub 2016 Mar 15

30. Valente FM, Sparago A, Freschi A, Hill-Harfe K, Maas SM, Frints SGM, Alders M, Pignata L, Franzese M, Angelini C, Carli D, Mussa A, Gazzin A, Gabbarini F, Acurzio B, Ferrero GB, Bliek J, Williams CA, Riccio A, Cerrato F. Transcription alterations of KCNQ1 associated with imprinted methylation defects in the Beckwith-Wiedemann locus. Genet Med 2019;21:1808-1820.

31. Rossignol S, Steunou V, Chalas C, Kerjean A, Rigolet M, ViegasPequignot E, Jouannet P, Le Bouc Y, Gicquel C. The epigenetic imprinting defect of patients with Beckwith-Wiedemann syndrome born after assisted reproductive technology is not restricted to the 11 p1 5 region. J Med Genet 2006;43:902-907. Epub 2006 Jul 6

32. Fontana L, Bedeschi MF, Maitz S, Cereda A, Faré C, Motta S, Seresini A, D’Ursi P, Orro A, Pecile V, Calvello M, Selicorni A, Lalatta F, Milani D, Sirchia SM, Miozzo M, Tabano S. Characterization of multi-locus imprinting disturbances and underlying genetic defects in patients with chromosome $11 \mathrm{p} 15.5$ related imprinting disorders. Epigenetics 2018;13:897-909. Epub 2018 Oct 21 
33. Meyer E, Lim D, Pasha S, Tee LJ, Rahman F, Yates JR, Woods CG, Reik W, Maher ER. Germline Mutation in NLRP2 (NALP2) in a Familial Imprinting Disorder (Beckwith-Wiedemann Syndrome). PLoS Genet 2009;5:1000423.

34. Court F, Martin-Trujillo A, Romanelli V, Garin I, Iglesias-Platas I, Salafsky I, Guitart M, Perez de Nanclares G, Lapunzina P, Monk D. Genome-Wide Allelic Methylation Analysis Reveals DiseaseSpecific Susceptibility to Multiple Methylation Defects in Imprinting Syndromes. Hum Mutat 2013;34:595-602. Epub 2013 Feb 19

35. Begemann M, Rezwan FI, Beygo J, Docherty LE, Kolarova J, Schroeder C, Buiting K, Chokkalingam K, Degenhardt F, Wakeling EL, Kleinle S, González Fassrainer D, Oehl-Jaschkowitz B, Turner CLS, Patalan M, Gizewska M, Binder G, Bich Ngoc CT, Chi Dung V, Mehta SG, Baynam G, Hamilton-Shield JP, Aljareh S, Lokulo-Sodipe O, Horton R, Siebert R, Elbracht M, Temple IK9, Eggermann T, Mackay DJG. Maternal variants in NLRP and other maternal effect proteins are associated with multilocus imprinting disturbance in offspring. J Med Genet 2018;55:497-504.

36. Tian X, Pascal G, Monget P. Evolution and functional divergence of NLRP genes in mammalian reproductive systems. BMC Evol Biol 2009;9:202.

37. Duéñez-Guzmán E, Haig D. The Evolution of Reproduction-Related NLRP Genes. J Mol Evol 2014;78:194-201. Epub 2014 Mar 11

38. Soellner L, Monk D, Rezwan FI, Begemann M, Mackay D, Eggermann T. Congenital imprinting disorders: Application of multilocus and high throughput methods to decipher new pathomechanisms and improve their management. Mol Cell Probes 2015;29:282-290. Epub 2015 Jun 10

39. Docherty LE, Rezwan FI, Poole RL, Turner CL, Kivuva E, Maher ER, Smithson SF, Hamilton-Shield JP, Patalan M, Gizewska M, Peregud-Pogorzelski J, Beygo J, Buiting K, Horsthemke B, Soellner L, Begemann M, Eggermann T, Baple E, Mansour S, Temple IK, Mackay DJ. Mutations in NLRP5 are associated with reproductive wastage and multilocus imprinting disorders in humans. Nat Commun 2015;6:8086

40. Kalish JM, Conlin LK, Bhatti TR, Dubbs HA, Harris MC, Izumi K, Mostoufi-Moab S, Mulchandani S, Saitta S, States LJ, Swarr DT, Wilkens AB, Zackai EH, Zelley K, Bartolomei MS, Nichols KE, Palladino AA, Spinner NB, Deardorff MA. Clinical features of three girls with mosaic genome-wide paternal uniparental isodisomy. Am J Med Genet A 2013;161:1929-1939. Epub 2013 Jun 26

41. Abi Habib W, Azzi S, Brioude F, Steunou V, Thibaud N, Das Neves C, Le Jule M, Chantot-Bastaraud S, Keren B, Lyonnet S, Michot C, Rossi M, Pasquier L, Gicquel C, Rossignol S, Le Bouc Y, Netchine I. Extensive investigation of the IGF2/H19 imprinting control region reveals novel OCT4/SOX2 binding site defects associated with specific methylation patterns in Beckwith-Wiedemann syndrome. Hum Mol Genet 2014;23:5763-5773. Epub 2014 Jun 10

42. Zimmerman DL, Boddy CS, Schoenherr CS. Oct4/Sox2 Binding Sites Contribute to Maintaining Hypomethylation of the Maternal Igf $2 / \mathrm{H} 19$ Imprinting Control Region. PLoS One 2013;8:81962.

43. Liu W, Zhang R, Wei J, Zhang H, Yu G, Li Z, Chen M, Sun X. Rapid Diagnosis of Imprinting Disorders Involving Copy Number Variation and Uniparental Disomy Using Genome-Wide SNP Microarrays. Cytogenet Genome Res 2015;146:9-18. Epub 2015 Jul 16

44. Russo S, Calzari L, Mussa A, Mainini E, Cassina M, Di Candia S, Clementi M, Guzzetti S, Tabano S, Miozzo M, Sirchia S, Finelli P, Prontera P, Maitz S, Sorge G, Calcagno A, Maghnie M, Divizia MT, Melis D, Manfredini E, Ferrero GB, Pecile V, Larizza L. A multimethod approach to the molecular diagnosis of overt and borderline 11 p15.5 defects underlying Silver-Russell and Beckwith-Wiedemann syndromes. Clin Epigenetics 2016;8:23.
45. Mussa A, Molinatto C, Baldassarre G, Riberi E, Russo S, Larizza L, Riccio A, Ferrero GB. Cancer Risk in Beckwith-Wiedemann Syndrome: A Systematic Review and Meta-Analysis Outlining a Novel (Epi) Genotype Specific Histotype Targeted Screening Protocol. J Pediatr 2016;176:142-149. Epub 2016 Jun 29

46. Maas SM, Vansenne F, Kadouch DJ, Ibrahim A, Bliek J, Hopman S, Mannens MM, Merks JH, Maher ER, Hennekam RC. Phenotype, cancer risk, and surveillance in Beckwith-Wiedemann syndrome depending on molecular genetic subgroups. Am J Med Genet A 2016;170:2248-2260. Epub 2016 Jul 15

47. Mussa A, Ferrero GB. Screening Hepatoblastoma in BeckwithWiedemann Syndrome: A Complex Issue. J Pediatr Hematol Oncol 2015;37:627.

48. Mussa A, Ferrero GB. Serum alpha-fetoprotein screening for hepatoblastoma in Beckwith-Wiedemann syndrome. Am J Med Genet A 2017;173:585-587.

49. Mussa A, Di Candia S, Russo S, Catania S, De Pellegrin M, Di Luzio L, Ferrari M, Tortora C, Meazzini MC, Brusati R, Milani D, Zampino G, Montirosso R, Riccio A, Selicorni A, Cocchi G, Ferrero GB. Recommendations of the Scientific Committee of the Italian Beckwith-Wiedemann Syndrome Association on the diagnosis, management and follow-up of the syndrome. Eur J Med Genet 2016;59:52-64. Epub 2015 Nov 22

50. Mussa A, Pagliardini S, Pagliardini V, Molinatto C, Baldassarre G, Corrias A, Silengo MC, Ferrero GB. $\alpha$-Fetoprotein assay on dried blood spot for hepatoblastoma screening in children with overgrowthcancer predisposition syndromes. Pediatr Res 2014;76:544-548. Epub 2014 Aug 28

51. Mussa A, Ciuffreda VP, Sauro P, Pagliardini V, Pagliardini S, Carli D, Kalish JM8, Fagioli F9,10, Pavanello E11, Ferrero GB. Longitudinal Monitoring of Alpha-Fetoprotein by Dried Blood Spot for Hepatoblastoma Screening in Beckwith-Wiedemann Syndrome. Cancers (Basel) 2019:11.

52. Mussa A, Duffy KA, Carli D, Ferrero GB, Kalish JM. Defining an optimal time window to screen for hepatoblastoma in children with BeckwithWiedemann syndrome. Pediatr Blood Cancer 2019;66:27492. Epub 2018 Sep 30

53. Saal HM. Russell-Silver Syndrome. In: Adam MP, Ardinger HH, Pagon RA, Wallace SE, Bean LJ, Stephens K (eds). GeneReviews ${ }^{\circledR}$ [Internet]. Seattle (WA): University of Washington, Seattle; 1993 [cited 2019 Jan 16]. Available from: http://www.ncbi.nlm.nih.gov/books/NBK1324/

54. Azzi S, Salem J, Thibaud N, Chantot-Bastaraud S, Lieber E, Netchine I, Harbison MD. A prospective study validating a clinical scoring system and demonstrating phenotypical-genotypical correlations in SilverRussell syndrome. J Med Genet 2015;52:446-453. Epub 2015 May 7

55. Gicquel C, Rossignol S, Cabrol S, Houang M, Steunou V, Barbu V, Danton F, Thibaud N, Merrer ML, Burglen L, Bertrand AM, Netchine I, Bouc YL. Epimutation of the telomeric imprinting center region on chromosome $11 \mathrm{p} 15$ in Silver-Russell syndrome. Nat Genet 2005;37:1003-1007. Epub 2012 Jan 16

56. Demars J, Gicquel C. Epigenetic and genetic disturbance of the imprinted 11 p15 region in Beckwith-Wiedemann and Silver-Russell syndromes. Clin Genet 2012;81:350-361. Epub 2012 Jan 16

57. Begemann M, Spengler S, Gogiel M, Grasshoff U, Bonin M, Betz RC, Dufke A, Spier I, Eggermann T. Clinical significance of copy number variations in the 11 p15.5 imprinting control regions: new cases and review of the literature. J Med Genet 2012;49:547-553. Epub 2012 Jul 26

58. Cytrynbaum C, Chong K, Hannig V, Choufani S, Shuman C, Steele L, Morgan T, Scherer SW, Stavropoulos DJ, Basran RK, Weksberg R. Genomic imbalance in the centromeric 11 p15 imprinting center in 
three families: Further evidence of a role for IC2 as a cause of RussellSilver syndrome. Am J Med Genet A 2016;170:2731-2739. Epub 2016 Jul 4

59. Brioude F, Oliver-Petit I, Blaise A, Praz F, Rossignol S, Le Jule M, Thibaud N, Faussat AM, Tauber M, Le Bouc Y, Netchine I. CDKN1C mutation affecting the PCNA-binding domain as a cause of familial Russell Silver syndrome. J Med Genet 2013;50:823-830. Epub 2013 Sep 24

60. Begemann M, Zirn B, Santen G, Wirthgen E, Soellner L, Büttel HM, Schweizer R, van Workum W, Binder G, Eggermann T. Paternally Inherited IGF2 Mutation and Growth Restriction. N Engl J Med 2015;373:349-356. Epub 2015 Jul 8

61. De Crescenzo A, Citro V, Freschi A, Sparago A, Palumbo O, Cubellis MV, Carella M, Castelluccio P, Cavaliere ML, Cerrato F, Riccio A. A splicing mutation of the HMGA2 gene is associated with Silver-Russell syndrome phenotype. J Hum Genet 2015;60:287-293. Epub 2015 Mar 26.

62. Leszinski GS, Warncke K, Hoefele J, Wagner M. A case report and review of the literature indicate that HMGA2 should be added as a disease gene for Silver-Russell syndrome. Gene 2018;663:110-114. Epub 2018 Apr 12

63. Abi Habib W, Brioude F, Edouard T, Bennett JT, Lienhardt-Roussie A, Tixier F, Salem J, Yuen T, Azzi S, Le Bouc Y, Harbison MD, Netchine I. Genetic disruption of the oncogenic HMGA2-PLAG1-IGF2 pathway causes fetal growth restriction. Genet Med 2018;20:250-258. Epub 2017 Aug 10

64. Eggermann T, Binder G, Brioude F, Maher ER, Lapunzina P, Cubellis MV, Bergadá I, Prawitt D, Begemann M. CDKN1C mutations: two sides of the same coin. Trends Mol Med 2014;20:61 4-622. Epub 2014 Sep 25

65. Bennett J, Schrier Vergano SA, Deardorff MA. IMAGe Syndrome. In: Adam MP, Ardinger HH, Pagon RA, Wallace SE, Bean LJ, Stephens K (eds). GeneReviews ${ }^{\circledR}$ [Internet]. Seattle (WA): University of Washington, Seattle; 1993 [cited 2019 Jan 16]. Available from: http:// www.ncbi.nlm.nih.gov/books/NBK190103/

66. Ioannides Y, Lokulo-Sodipe K, Mackay DJ, Davies JH, Temple IK. Temple syndrome: improving the recognition of an underdiagnosed chromosome 14 imprinting disorder: an analysis of 51 published cases. J Med Genet 2014;51:495-501. Epub 2014 Jun 2

67. Mitter D, Buiting $\mathrm{K}$, von Eggeling $\mathrm{F}$, Kuechler A, Liehr T, MauHolzmann UA, Prott EC, Wieczorek D, Gillessen-Kaesbach G. Is there a higher incidence of maternal uniparental disomy 14 [upd(14)mat]? Detection of 10 new patients by methylation-specific PCR. Am J Med Genet A 2006;140:2039-2049.

68. Poole RL, Docherty LE, Al Sayegh A, Caliebe A, Turner C, Baple E, Wakeling E, Harrison L, Lehmann A, Temple IK, Mackay DJ; International Clinical Imprinting Consortium. Targeted methylation testing of a patient cohort broadens the epigenetic and clinical description of imprinting disorders. Am J Med Genet A 2013;161:21742182. Epub 2013 Aug 2

69. Luk HM. Temple syndrome misdiagnosed as Silver-Russell syndrome. Clin Dysmorphol 2016;25:82-83.

70. Brightman DS, Lokulo-Sodipe O, Searle BA, Mackay DJG, Davies JH, Temple IK, Dauber A. Growth hormone improves short-term growth in patients with Temple Syndrome. Horm Res Paediatr 2018;90:407413 Epub 2019 Mar 5

71. Kagami M, Sekita Y, Nishimura G, Irie M, Kato F, Okada M, Yamamori S, Kishimoto H, Nakayama M, Tanaka Y, Matsuoka K, Takahashi T, Noguchi M, Tanaka Y, Masumoto K, Utsunomiya T, Kouzan H, Komatsu Y, Ohashi H, Kurosawa K, Kosaki K, Ferguson-Smith AC, Ishino F, Ogata T. Deletions and epimutations affecting the human
$14 \mathrm{q} 32.2$ imprinted region in individuals with paternal and maternal upd(14)-like phenotypes. Nat Genet 2008;40:237-242. Epub 2008 Jan 6

72. Kagami M, O'Sullivan MJ, Green AJ, Watabe Y, Arisaka O, Masawa N, Matsuoka K, Fukami M, Matsubara K, Kato F, Ferguson-Smith AC, Ogata T. The IG-DMR and the MEG3-DMR at human chromosome 14932.2: hierarchical interaction and distinct functional properties as imprinting control centers. PLoS Genet 2010;6:e1000992.

73. Temple IK, Cockwell A, Hassold T, Pettay D, Jacobs P. Maternal uniparental disomy for chromosome 14. J Med Genet 1991;28:511 514.

74. Briggs TA, Lokulo-Sodipe K, Chandler KE, Mackay DJG, Temple IK. Temple syndrome as a result of isolated hypomethylation of the $14 \mathrm{q} 32$ imprinted DLK1/MEG3 region. Am J Med Genet A 2016;170:170-175. Epub 2015 Sep 23

75. Gillessen-Kaesbach G, Albrecht B, Eggermann T, Elbracht M, Mitter D, Morlot S, van Ravenswaaij-Arts CMA, Schulz S, Strobl-Wildemann G, Buiting K, Beygo J. Molecular and clinical studies in 8 patients with Temple syndrome. Clin Genet 2018;93:1179-1188. Epub 2018 Mar 25

76. Kagami M, Kurosawa K, Miyazaki O, Ishino F, Matsuoka K, Ogata T. Comprehensive clinical studies in 34 patients with molecularly defined UPD(14)pat and related conditions (Kagami-Ogata syndrome). Eur J Hum Genet 2015;23:1488-1498. Epub 2015 Feb 18

77. Ogata T, Kagami M. Kagami-Ogata syndrome: a clinically recognizable upd(14)pat and related disorder affecting the chromosome $14 \mathrm{q} 32.2$ imprinted region. J Hum Genet 2016;61:87-94. Epub 2015 Sep 17

78. Van Der Werf I, Buiting K, Czeschik C, Reyniers E, Vandeweyer G, Vanhaesebrouck P, Lüdecke HJ, Wieczorek D, Horsthemke B, Mortier G, Leroy JG, Kooy RF. Novel microdeletions on chromosome $14 \mathrm{q} 32.2$ suggest a potential role for non-coding RNAs in Kagami-Ogata syndrome. Eur J Hum Genet 2016;24:1724-1729. Epub 2016 Jul 13

79. Williams CA, Driscoll DJ, Dagli AI. Clinical and genetic aspects of Angelman syndrome. Genet Med 2010;12:385-395.

80. Dagli AI, Mueller J, Williams CA. Angelman Syndrome. In: Adam MP, Ardinger HH, Pagon RA, Wallace SE, Bean LJ, Stephens K (eds). GeneReviews ${ }^{\circledR}$ [Internet]. Seattle (WA): University of Washington, Seattle; 1993 [cited 2019 Jan 16]. Available from: http://www.ncbi. nlm.nih.gov/books/NBK1144/

81. Noor A, Dupuis L, Mittal K, Lionel AC, Marshall CR, Scherer SW, Stockley T, Vincent JB, Mendoza-Londono R, Stavropoulos DJ. 15q11.2 Duplication Encompassing Only the UBE3A Gene Is Associated with Developmental Delay and Neuropsychiatric Phenotypes. Hum Mutat 2015;36:689-693.

82. Meng L, Ward AJ, Chun S, Bennett CF, Beaudet AL, Rigo F. Towards a therapy for Angelman syndrome by targeting a long non-coding RNA. Nature 2015;518:409-412. Epub 2014 Dec 1

83. Brambilla P, Crinò A, Bedogni G, Bosio L, Cappa M, Corrias A, Delvecchio M, Di Candia S, Gargantini L, Grechi E, Iughetti L, Mussa A, Ragusa L, Sacco M, Salvatoni A, Chiumello G, Grugni G; Genetic Obesity Study Group of the Italian Society of Pediatric Endocrinology and Diabetology (ISPED). Metabolic syndrome in children with Prader-Willi syndrome: The effect of obesity. Nutr Metab Cardiovasc Dis 2011;21:269-276. Epub 2010 Jan 20

84. Driscoll DJ, Miller JL, Schwartz S, Cassidy SB. Prader-Willi Syndrome. In: Adam MP, Ardinger HH, Pagon RA, Wallace SE, Bean LJ, Stephens $K$ (eds). GeneReviews ${ }^{\circledR}$ [Internet]. Seattle (WA): University of Washington, Seattle; 1993 [cited 2019 Jan 16]. Available from: http:// www.ncbi.nlm.nih.gov/books/NBK1330/

85. Corrias A, Grugni G, Crinò A, Di Candia S, Chiabotto P, Cogliardi A, Chiumello G, De Medici C, Spera S, Gargantini L, Iughetti L, Luce A, Mariani B, Ragusa L, Salvatoni A, Andrulli S, Mussa A, Beccaria 
L; Study Group for Genetic Obesity of Italian Society of Pediatric Endocrinology and Diabetology (SIEDP/ISPED). Assessment of central adrenal insufficiency in children and adolescents with PraderWilli syndrome. Clin Endocrinol (Oxf) 2012;76:843-850.

86. Fountain MD Jr, Schaaf CP. MAGEL2 and Oxytocin-Implications in Prader-Willi Syndrome and Beyond. Biol Psychiatry 2015;78:78-80

87. Meziane H, Schaller F, Bauer S, Villard C, Matarazzo V, Riet F, Guillon G, Lafitte D, Desarmenien MG, Tauber M, Muscatelli F. An Early Postnatal Oxytocin Treatment Prevents Social and Learning Deficits in Adult Mice Deficient for Magel2, a Gene Involved in Prader-Willi Syndrome and Autism. Biol Psychiatry 2015;78:85-94. Epub 2014 Nov 20.

88. Gunay-Aygun M, Schwartz S, Heeger S, O'Riordan MA, Cassidy SB. The changing purpose of Prader-Willi syndrome clinical diagnostic criteria and proposed revised criteria. Pediatrics 2001;108:92.

89. Sahoo T, del Gaudio D, German JR, Shinawi M, Peters SU, Person RE, Garnica A, Cheung SW, Beaudet AL. Prader-Willi phenotype caused by paternal deficiency for the HBII-85 C/D box small nucleolar RNA cluster. Nat Genet 2008;40:719-721. Epub 2008 May 25

90. de Smith AJ, Purmann C, Walters RG, Ellis RJ, Holder SE, Van Haelst MM, Brady AF, Fairbrother UL, Dattani M, Keogh JM, Henning E, Yeo GS, O'Rahilly S, Froguel P, Faroogi IS, Blakemore AI. A deletion of the HBII-85 class of small nucleolar RNAs (snoRNAs) is associated with hyperphagia, obesity and hypogonadism. Hum Mol Genet 2009;18:3257-3265. Epub 2009 Jun 4

91. Buiting K, Saitoh S, Gross S, Dittrich B, Schwartz S, Nicholls RD, Horsthemke B. Inherited microdeletions in the Angelman and PraderWilli syndromes define an imprinting centre on human chromosome 15. Nat Genet 1995;9:395-400.

92. Fontana P, Grasso M, Acquaviva F, Gennaro E, Galli ML, Falco M, Scarano F, Scarano G, Lonardo F. SNORD116 deletions cause PraderWilli syndrome with a mild phenotype and macrocephaly. Clin Genet 2017;92:440-443. Epub 2017 Mar 30

93. Rocha CF, Paiva CL. Prader-Willi-like phenotypes: a systematic review of their chromosomal abnormalities. Genet Mol Res 2014;13:22902298.

94. Fountain MD, Aten E, Cho MT, Juusola J, Walkiewicz MA, Ray JW, Xia F, Yang Y, Graham BH, Bacino CA, Potocki L, van Haeringen A, Ruivenkamp CA, Mancias P, Northrup H, Kukolich MK, Weiss MM, van Ravenswaaij-Arts CM, Mathijssen IB, Levesque S, Meeks N, Rosenfeld JA, Lemke D, Hamosh A, Lewis SK, Race S, Stewart LL, Hay B, Lewis AM, Guerreiro RL, Bras JT, Martins MP, Derksen-Lubsen G, Peeters E, Stumpel C, Stegmann S, Bok LA, Santen GW, Schaaf CP. The phenotypic spectrum of Schaaf-Yang syndrome: 18 new affected individuals from 14 families. Genet Med 2017;19:45-52. Epub 2016 May 19

95. Bulcao Macedo D, Nahime Brito V, Latronico AC. New Causes of Central Precocious Puberty: The Role of Genetic Factors. Neuroendocrinology 2014;100:1-8. Epub 2014 Aug 9

96. Fuqua JS. Treatment and Outcomes of Precocious Puberty: An Update. J Clin Endocrinol Metab 2013;98:2198-2207. Epub 2013 Mar 20

97. Abreu AP, Dauber A, Macedo DB, Noel SD, Brito VN, Gill JC, Cukier P, Thompson IR, Navarro VM, Gagliardi PC, Rodrigues T, Kochi C, Longui CA, Beckers D, de Zegher F, Montenegro LR, Mendonca BB, Carroll RS, Hirschhorn JN, Latronico AC, Kaiser UB. Central Precocious Puberty Caused by Mutations in the Imprinted Gene MKRN3. N Engl J Med 2013;368:2467-2475. Epub 2013 Jun 5

98. Bessa DS, Macedo DB, Brito VN, França MM, Montenegro LR, CunhaSilva M, Silveira LG, Hummel T, Bergadá I, Braslavsky D, Abreu AP, Dauber A, Mendonca BB, Kaiser UB, Latronico AC. High Frequency of MKRN3 Mutations in Male Central Precocious Puberty Previously
Classified as Idiopathic. Neuroendocrinology 2017;105:17-25. Epub 2016 May 26

99. Hagen CP, Sørensen K, Mieritz MG, Johannsen TH, Almstrup K, Juul A. Circulating MKRN3 Levels Decline Prior to Pubertal Onset and Through Puberty: A Longitudinal Study of Healthy Girls. J Clin Endocrinol Metab 2015;100:1920-1926. Epub 2015 Feb 19

100. Busch AS, Hagen CP, Almstrup K, Juul A. Circulating MKRN3 Levels Decline During Puberty in Healthy Boys. J Clin Endocrinol Metab 2016;101:2588-2593. Epub 2016 Apr 8

101. Macedo DB, Abreu AP, Reis AC, Montenegro LR, Dauber A, Beneduzzi D, Cukier P, Silveira LF, Teles MG, Carroll RS, Junior GG, Filho GG, Gucev Z, Arnhold IJ, de Castro M, Moreira AC, Martinelli CE Jr, Hirschhorn JN, Mendonca BB, Brito VN, Antonini SR, Kaiser UB, Latronico AC. Central Precocious Puberty That Appears to Be Sporadic Caused by Paternally Inherited Mutations in the Imprinted Gene Makorin Ring Finger 3. J Clin Endocrinol Metab 2014;99:1097-1103. Epub 2014 Mar 14

102. Klein K, Yang J, Aisenberg J, Wright N, Kaplowitz P, Lahlou N, Linares J, Lundström E, Purcea D, Cassorla F. Efficacy and safety of triptorelin 6-month formulation in patients with central precocious puberty. J Pediatr Endocrinol Metab 2016;29:1241-1248.

103. Sachwitz J, Strobl-Wildemann G, Fekete G, Ambrozaitytè L, Kučinskas $\mathrm{V}$, Soellner L, Begemann M, Eggermann T. Examinations of maternal uniparental disomy and epimutations for chromosomes 6, 14, 16 and 20 in Silver-Russell syndrome-like phenotypes. BMC Med Genet 2016;17:20.

104. Eggermann T, Curtis M, Zerres K, Hughes HE. Maternal uniparental disomy 16 and genetic counseling: new case and survey of published cases. Genet Couns 2004;15:183-190.

105. Scheuvens R, Begemann M, Soellner L, Meschede D, Raabe-Meyer G, Elbracht M, Schubert R, Eggermann T. Maternal uniparental disomy of chromosome 16 [upd(16)mat]: clinical features are rather caused by (hidden) trisomy 16 mosaicism than by upd(16)mat itself. Clin Genet 2017;92:45-51. Epub 2017 Mar 8

106. Inoue $\mathrm{T}$, Yagasaki $\mathrm{H}$, Nishioka J, Nakamura $\mathrm{A}$, Matsubara $\mathrm{K}$, Narumi S, Nakabayashi K, Yamazawa K, Fuke T, Oka A, Ogata T, Fukami M, Kagami M. Molecular and clinical analyses of two patients with UPD(16)mat detected by screening 94 patients with SilverRussell syndrome phenotype of unknown aetiology. J Med Genet 2019;56:413-418. Epub 2018 Sep 21.

107. Mantovani G, Spada A. Mutations in the Gs alpha gene causing hormone resistance. Best Pract Res Clin Endocrinol Metab 2006;20:501-513.

108. Underbjerg L, Sikjaer T, Mosekilde L, Rejnmark L. Pseudohypoparathyroidism - epidemiology, mortality and risk of complications. Clin Endocrinol (Oxf) 2016;84:904-911. Epub 2015 Oct 19

109. Elli FM, Linglart A, Garin I, de Sanctis L, Bordogna P, Grybek V, Pereda A, Giachero F, Verrua E, Hanna P, Mantovani G, Perez de Nanclares G. The Prevalence of GNAS Deficiency-Related Diseases in a Large Cohort of Patients Characterized by the EuroPHP Network. J Clin Endocrinol Metab 2016;101:3657-3668. Epub 2016 Jul 18

110. Thiele S, Mantovani G, Barlier A, Boldrin V, Bordogna P, De Sanctis L, Elli FM, Freson K, Garin I, Grybek V, Hanna P, Izzi B, Hiort O, Lecumberri B, Pereda A, Saraff V, Silve C, Turan S, Usardi A, Werner R, de Nanclares GP, Linglart A. From pseudohypoparathyroidism to inactivating PTH/PTHrP signalling disorder (iPPSD), a novel classification proposed by the EuroPHP network. Eur J Endocrinol 2016;175:1-17. Epub 2016 Jul 11

111. Linglart A, Maupetit-Méhouas S, Silve C. GNAS-Related Loss-ofFunction Disorders and the Role of Imprinting. Horm Res Paediatr 2013;79:119-129. Epub 2013 Mar 29 
112. Crane JL, Shamblott MJ, Axelman J, Hsu S, Levine MA, Germain-Lee EL. Imprinting status of Galpha(s), NESP55, and XLalphas in cell cultures derived from human embryonic germ cells: GNAS imprinting in human embryonic germ cells. Clin Transl Sci 2009;2:355-360.

113. Roizen JD, Danzig J, Groleau V, McCormack S, Casella A, Harrington J, Sochett E, Tershakovec A, Zemel BS, Stallings VA, Levine MA. Resting Energy Expenditure Is Decreased in Pseudohypoparathyroidism Type 1A. J Clin Endocrinol Metab 2016;101:880-888. Epub 2015 Dec 28

114. Simpson C, Grove E, Houston BA. Pseudopseudohypoparathyroidism. Lancet 2015;385:1123. Epub 2014 Dec 5

115. Adegbite NS, Xu M, Kaplan FS, Shore EM, Pignolo RJ. Diagnostic and mutational spectrum of progressive osseous heteroplasia $(\mathrm{POH})$ and other forms of GNAS -based heterotopic ossification. Am J Med Genet A 2008;146:1788-1796.

116. Zazo C, Thiele S, Martín C, Fernandez-Rebollo E, Martinez-Indart L, Werner R, Garin I; Spanish PHP Group, Hiort O, Perez de Nanclares G. Gs $\alpha$ activity is reduced in erythrocyte membranes of patients with psedohypoparathyroidism due to epigenetic alterations at the GNAS locus. J Bone Miner Res 2011;26:1864-1870.
117. Mariot V, Maupetit-Méhouas S, Sinding C, Kottler ML, Linglart A. A maternal epimutation of GNAS leads to Albright osteodystrophy and parathyroid hormone resistance. J Clin Endocrinol Metab 2008;93:661-665. Epub 2008 Jan 8

118. Jüppner H, Linglart A, Fröhlich LF, Bastepe M. Autosomaldominant pseudohypoparathyroidism type $\mathrm{Ib}$ is caused by different microdeletions within or upstream of the GNAS locus. Ann N Y Acad Sci 2006;1068:250-255.

119. Perez-Nanclares G, Velayos T, Vela A, Muñoz-Torres M, Castaño L. Pseudohypoparathyroidism type Ib associated with novel duplications in the GNAS locus. PLOS ONE 2015;10:e0117691.

120. Mulchandani S, Bhoj EJ, Luo M, Powell-Hamilton N, Jenny K, Gripp KW, Elbracht M, Eggermann T, Turner CL, Temple IK, Mackay DJ, Dubbs H, Stevenson DA, Slattery L, Zackai EH, Spinner NB, Krantz ID, Conlin LK. Maternal uniparental disomy of chromosome 20: a novel imprinting disorder of growth failure. Genet Med 2015;1 8:309315. Epub 2015 Aug 6 